\title{
Geoengineering Characterization of the Rock Masses of Northern Face of Jabal Sabir, Taiz City, Yemen
}

\author{
Abdul-Aleam Ahmed A. D. Al-Qadhi ${ }^{1}$, M.R. Janardhana ${ }^{2}$ \\ ${ }^{1,2}$ Department of Geology, Yuvaraja's College, University of Mysore, Mysuru, India \\ Department of Computer Science, XYZ University, Coimbatore-46 \\ (Email ${ }^{1}$ : abdul.aleam.q@gmail.com,Email ${ }^{2}$ :drmrjanardhana@rediffmail.com)
}

\begin{abstract}
This paper is aimed at the description and the geotechnical characterization of the Tertiary granitic rock masses of the northern face of Sabir Mountain, Taiz city, Yemen, for the first time. For accomplishing this task, direct and indirect approaches are adopted. The direct approach is represented by field and laboratory investigations. Field investigations include discontinuity (joints) measurements/evaluation, applied Rock Mass Rating (RMR) system and Geological Strength Index (GSI) system, in addition to field tests, while laboratory investigations encompass physico-mechanical tests carried out on granitic rock materials. Indirect approach for the estimation of shear strength parameters $(\mathrm{c}, \varnothing)$, compressive strength $\left(\sigma_{\mathrm{cm}}\right)$, tensile strength $\left(\sigma_{\mathrm{tm}}\right)$ and deformation modulus $\left(\mathrm{E}_{\mathrm{rm}}\right)$ of these rock masses was made by applying the generalized Hoek-Brown failure criterion using geotechnical Roc-Lab software. The laboratory results indicate that the Tertiary granitic rock masses show wide range of variations in their physico-mechanical characteristics owing to degree of weathering /alteration and microfractures. The intact samples of Sabir granitic (Tg) rocks show "Moderate" to "High" density, "Low" to "Medium" porosity, "Good" to "Marginal" water absorption capacity and "Weak" to "Very Strong" strength. Stereographically, three main sets of discontinuities (joints) are identified at each station; however, the fourth joint set occurs, in addition to random joint sets. The discontinuities (joints) trend predominately in NE-SW and NW-SE directions in conformity with the regional structures or faults. According to $\mathrm{Jv} \mathrm{j} / \mathrm{m}^{3}$ values, the degree of jointing of these rock masses are varied from "Moderate" to "High" jointing. These rocks are categorized as "Fair" to "Excellent" quality, "Fair" to "Good/Very Good" quality and "Poor" to "Very Good" quality classes according to RQD, RMR ${ }_{\mathrm{b} 89}$ and GSI respectively. Values of the shear strength parameters (c and $\left.\varnothing\right)$ and the other rock mass parameters $\left(\sigma_{\mathrm{tm}}, \sigma_{\mathrm{c}}, \sigma_{\mathrm{cm}}\right.$ and $\left.\mathrm{E}_{\mathrm{rm}}\right)$ show variations depending on the rock mass quality and properties of intact rock. However, in general the values of the rock mass parameters are found to increase with increase in the quality of rock mass and intact rock properties.
\end{abstract}

Keywords - Geoengineering characterization, GSI, RMR, Rock mass parameters, Sabir granite

\section{INTRODUCTION}

The Miocene Sabir granitic body forms one of the Tertiary intrusive bodies exposed in various locations, especially in the south and along the western escarpment slopes of Yemen highlands, running nearly parallel to the general trend of the Red Sea. It has occupied the southern part of Taiz city, located far southwestern part of Yemen Republic and is bounded approximately by longitudes $387862 \mathrm{E}$ and $402165 \mathrm{E}$ and latitudes $1488685 \mathrm{~N}$ and 1499862N (Fig.1). The contents of each section may be provided to understand easily about the paper. Jabal Sabir granitic rock masses form the dominant morphological feature (Sabir Mountain) overlooking the city of Taiz from south (Figs. 1 \& 2) and has been emplaced as a laccolithic body inside the older stratified Tertiary Yemen volcanic rocks. It occupies about $96 \mathrm{~km}^{2}$ of the total Taiz area with elevation reaching up $3070 \mathrm{~m}$ above mean sea level and is characterized by high lands, steep slopes and deep valleys. Physical weathering of varying intensities has produced different sizes of granitic blocks and boulders along the slope sides. Infrastructural development in these regions is a formidable task with considerable geotechnical problems such as steep slopes, presence of different sizes of unstable granitic blocks and boulders, joints, weathering /alteration and excavations implemented by human.

Planning and designing of infrastructure without due consideration to these problems may pose the infrastructure as well as the environment at risk. The geoengineering characterization of rock masses during, before and after the construction of any project in this area is essential. In this study, the northern face of Jabal Sabir covering an area of $21.40 \mathrm{~km}^{2}$ was selected for geotechnical investigation because relatively significant part of Taiz city is built on foot hills and slope regions of this Mountain.

Geologically (including petrogenesis), the Sabir granitic masses have been studied by $[1,2,3$, 

ISSN : 2248-9622, Vol. 7, Issue 4, ( Part -2) April 2017, pp.71-83

4, 5 \& 6]. Sabir granitic masses are represented by alkaline or peralkaline granites. They are white to greyish white, massive, medium to coarse-grained rocks at places grading up to granite porphyry and consist almost $<5 \%$ of melanocratic minerals (dark). These rocks essentially consist of k-feldspar, quartz, hornblende and biotite. The thin sections studied by Al-Qadhi [6] indicated that Sabir granitic rocks largely consist of k-feldspar (orthoclase, perthite, and perthitic microcline), quartz, hornblende and biotite with zircon and opaques as accessory minerals. The spheroidal and cavernous weathering is one of characteristic features of Sabir granitic rocks. The caverns of various sizes and shapes were observed in different locations. Sabir granitic rock masses are cut by different shapes and sizes of mafic and felsic dykes.

From the geotechnical point of view, the knowledge about the Sabir granitic rocks or engineering geology is very scarce. The only research work to be mentioned is the work of AlQadhi [6] who has carried out geo-engineering assessment of some of the rocky outcrops. The present situation warrants the geotechnical assessment of Sabir granitic rock masses of Taiz area as the city is witnessing rapid growth owing to urbanization.

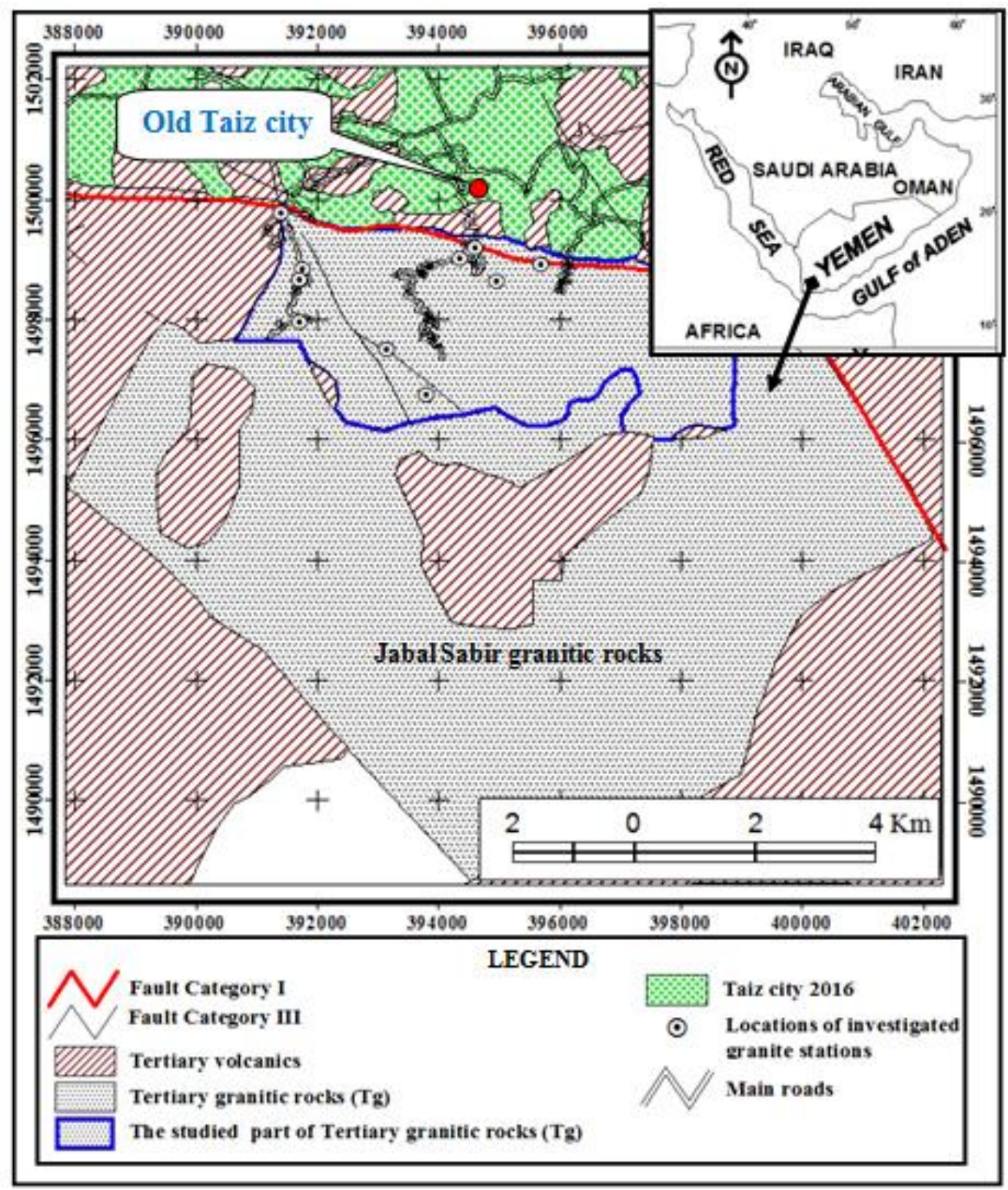

Figure 1 Geological map of the study area (modified after [7, 8, $9 \& 10]$ showing locations of the investigated stations 


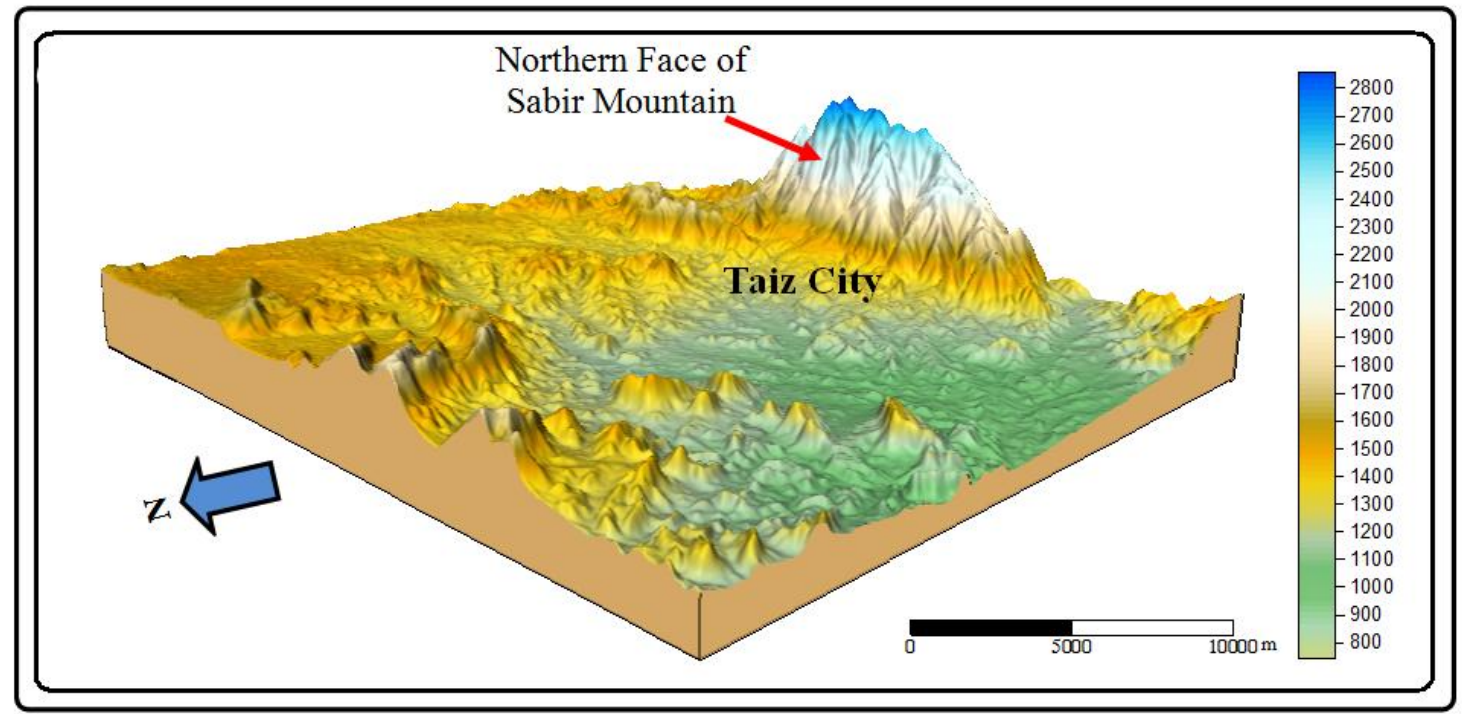

Figure 2 3D Model (DEM) illustrates the northern face of Sabir Mountain and its features

\subsection{Field Procedures}

\section{METHODOLOGY}

Site investigations were carried out on exposures of Sabir granitic rock masses along road cuts and on the natural rock outcrops at 16 locations; 10 of them were chosen to be representative field stations or sites (Fig.1). At each representative site, the rock mass was divided into a number of rock mass units or zones based on change in lithology and rock mass structural properties and according to the guidelines prescribed by Bieniawski [11]. Field scanline (tape) surveys [12] were carried out to record discontinuity in three dimensions (as possible) and the following characteristics [13] were recorded: orientation or attitude of discontinuity (dip/dip direction (deg.)), persistence (m), aperture $(\mathrm{mm})$, roughness, state and thickness of filling material, water flow and wall weathering (Table1). The discontinuity orientations data was plotted stereographically (equal-area stereographic projection) using RockWorks/14 (Rock- Ware) [14], and the joint sets were distinguished for all scanline data and then the pole concentrations were contoured. The maximum density points or average density on the contour diagram were selected as the best representation of the orientation of each discontinuity set (Table 1). The mean discontinuity spacing was calculated for each recognized discontinuity set. Occurrence of more than one set of discontinuity and the existence of more complicated jointing patterns prompted the present investigators to give the lowest (minimum) rating for spacing [15]. Where the measurements are possible on the rock exposures in three dimensions, the volumetric joint count $\left(\mathrm{Jv} \mathrm{j} / \mathrm{m}^{3}\right)$ is measured. It was measured from the joint set spacings within a volume of rock mass [16, 17, 18, $19 \&$ 20]. Random joints are included because they represent a significant part of the number of measured discontinuities, neglecting them would lead to erroneous quantifications of the discontinuity nature of rock mass [21]. As suggested by Palmström [16], the spacing of $5 \mathrm{~m}$ for each random joint was taken, thus, the volumetric joint count (Jv) can be generally expressed as:

$$
\mathrm{Jv}=1 / \mathrm{S} 1+1 / \mathrm{S} 2 \ldots \ldots \ldots 1 / \mathrm{Sn}+\mathrm{Nr} /(5 \sqrt{\mathrm{A}})
$$

............ (1) (Table 2), where $\mathrm{S} 1, \mathrm{~S} 2$ and $\mathrm{S} 3$ are the average spacings for the joint sets, $\mathrm{Nr}$ is the number of random joints in the actual location and $\mathrm{A}$ is the area in $\mathrm{m}^{2}$.

In this study, the obtained values of $\mathrm{Jv}$ index were used to determine the Rock Quality Designation (RQD) [22] (Table 2) based on the following Equation:

$\mathrm{RQD}=110-2.5 \mathrm{Jv} \ldots \ldots \ldots \ldots \ldots$ (2), where RQD $=0$ for $\mathrm{Jv}>44$ and $\mathrm{RQD}=100$ for $\mathrm{Jv}<4$. 
Table 1 Characteristics of the discontinuities and calculation of GSI parameters for Sabir granitic rock masses in the study area

\begin{tabular}{|c|c|c|c|c|c|c|c|c|c|c|c|c|c|}
\hline \multicolumn{3}{|l|}{$\begin{array}{l}\text { Station no. } \\
\text { St }\end{array}$} & 74 & 76 & 77 & 80 & 81 & 85 & 86 & 88 & 90 & 91 & Remark \\
\hline \multirow{2}{*}{\multicolumn{3}{|c|}{$\begin{array}{l}\text { Zone } \\
\text { Zone thickness (m) }\end{array}$}} & I & I & I & I & I & I & I & I & I & I & From field observations \\
\hline & & & $>20$ & 38 & 6.4 & $>6.3$ & $>11.7$ & $>60$ & 6.5 & $>10.80$ & $>9$ & $>4.9$ & From field measurements \\
\hline \multirow{6}{*}{ 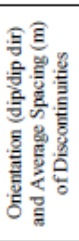 } & \multirow{4}{*}{ 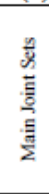 } & Setl & $\begin{array}{l}83 / 284 \\
(1.16)\end{array}$ & $\begin{array}{l}55 / 047 \\
(0.24)\end{array}$ & $\begin{array}{l}63 / 213 \\
(0.22)\end{array}$ & $\begin{array}{l}55 / 172 \\
(0.90)\end{array}$ & $\begin{array}{l}30 / 218 \\
(0.62)\end{array}$ & $\begin{array}{l}59 / 160 \\
(0.98)\end{array}$ & $\begin{array}{c}26 / 173 \\
(0.13)\end{array}$ & $\begin{array}{l}67 / 349 \\
(0.62)\end{array}$ & $\begin{array}{l}51 / 310 \\
(1.13)\end{array}$ & $\begin{array}{c}47 / 153 \\
(0.29)\end{array}$ & \multirow{5}{*}{$\begin{array}{l}\text { From field measurements } \\
\text { and stereonet }\end{array}$} \\
\hline & & Set2 & $\begin{array}{l}23 / 175 \\
(0.31)\end{array}$ & $\begin{array}{l}62 / 218 \\
(0.28)\end{array}$ & $\begin{array}{c}47 / 342 \\
(0.33)\end{array}$ & $\begin{array}{l}69 / 079 \\
(0.64)\end{array}$ & $\begin{array}{l}81 / 124 \\
(0.59)\end{array}$ & $\begin{array}{l}56 / 329 \\
(1.08)\end{array}$ & $\begin{array}{l}81 / 008 \\
(0.26)\end{array}$ & $\begin{array}{l}75 / 134 \\
(1.11)\end{array}$ & $\begin{array}{l}68 / 107 \\
(0.71)\end{array}$ & $\begin{array}{l}70 / 281 \\
(0.32)\end{array}$ & \\
\hline & & Set3 & $\begin{array}{l}81 / 013 \\
(1.20)\end{array}$ & $\begin{array}{c}77 / 113 \\
(0.60)\end{array}$ & $\begin{array}{l}84 / 091 \\
(0.16) \\
\end{array}$ & $\begin{array}{l}58 / 307 \\
(1.15)\end{array}$ & $\begin{array}{l}75 / 039 \\
(1.27) \\
\end{array}$ & $\begin{array}{l}81 / 237 \\
(0.62)\end{array}$ & $\begin{array}{l}41 / 244 \\
(0.23) \\
\end{array}$ & $\begin{array}{l}41 / 222 \\
(0.55)\end{array}$ & $\begin{array}{l}81 / 190 \\
(0.62)\end{array}$ & $\begin{array}{c}74 / 056 \\
(0.56)\end{array}$ & \\
\hline & & Set4 & - & $\begin{array}{l}69 / 312 \\
(0.54)\end{array}$ & - & - & - & - & - & - & - & - & \\
\hline & \multicolumn{2}{|c|}{ Set 4/5(random) } & $5 / 2=2.5$ & $5 / 2=2.5$ & $5 / 4=1.25$ & - & $5 / 2=2.5$ & - & $5 / 4=1.25$ & - & $5 / 2=2.5$ & $5 / 2=2.5$ & \\
\hline & \multirow{2}{*}{\multicolumn{2}{|c|}{$\begin{array}{l}\text { Min Spacing } \\
\text { r condition }\end{array}$}} & 0.31 & 0.24 & 0.16 & 0.64 & 0.59 & 0.62 & 0.13 & 0.55 & 0.62 & 0.29 & From field measurements \\
\hline Ground water condition & & & Dry & Dry & Dry & Dry & Dry & Dry & Dry & Dry & Dry & Dry & From field ol \\
\hline \multirow{5}{*}{ 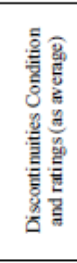 } & \multicolumn{2}{|c|}{$\begin{array}{c}\text { Persistence }(m) \\
\text { [Rating] }\end{array}$} & $\begin{array}{c}<1-10 \\
{[4]}\end{array}$ & $\begin{array}{c}<1->20 \\
{[3]}\end{array}$ & $\begin{array}{c}<1-3 \\
{[5]}\end{array}$ & $\begin{array}{l}<1-10 \\
{[4]}\end{array}$ & $\begin{array}{l}<1-3 \\
{[5]}\end{array}$ & $\begin{array}{c}<1->20 \\
{[3]}\end{array}$ & $\begin{array}{l}<1 \\
{[6]}\end{array}$ & $\begin{array}{l}<1-10 \\
{[4]}\end{array}$ & $\begin{array}{l}<1-10 \\
{[4]}\end{array}$ & $\begin{array}{l}41-10 \\
{[4]}\end{array}$ & \\
\hline & \multicolumn{2}{|c|}{$\begin{array}{c}\text { Aperture (mm) } \\
\text { [Rating] }\end{array}$} & $\begin{array}{l}1-5 \\
{[1]}\end{array}$ & $\begin{array}{l}35 \\
{[0]}\end{array}$ & $\begin{array}{l}>5 \\
{[0]}\end{array}$ & $\begin{array}{l}1-5 \\
{[1]}\end{array}$ & $\begin{array}{l}35 \\
{[0]}\end{array}$ & $\begin{array}{l}>5 \\
{[0]}\end{array}$ & $\begin{array}{l}>5 \\
{[0]}\end{array}$ & $\begin{array}{l}1-5 \\
{[1]}\end{array}$ & $\begin{array}{l}>5 \\
{[0]}\end{array}$ & $\begin{array}{l}>5 \\
{[0]}\end{array}$ & \\
\hline & \multicolumn{2}{|c|}{$\begin{array}{c}\text { Roughness } \\
\text { [Rating] }\end{array}$} & $\begin{array}{c}\text { Rough } \\
{[5]}\end{array}$ & $\begin{array}{l}\text { S. rough } \\
\text { [3] }\end{array}$ & $\begin{array}{c}\text { Smooth } \\
{[1]}\end{array}$ & $\begin{array}{c}\text { Rough } \\
\text { [5] }\end{array}$ & $\begin{array}{c}\text { Rough } \\
{[5]}\end{array}$ & $\begin{array}{c}\text { Rough } \\
{[5]}\end{array}$ & $\begin{array}{l}\text { Smooth } \\
{[1]}\end{array}$ & $\begin{array}{c}\text { Rough } \\
{[5]}\end{array}$ & $\begin{array}{c}\text { Rough } \\
{[5]}\end{array}$ & $\begin{array}{l}\text { S. rough } \\
\text { [3] }\end{array}$ & $\begin{array}{l}\text { From field observations } \\
\text { and Table of }\end{array}$ \\
\hline & \multicolumn{2}{|c|}{$\begin{array}{l}\text { Infilling } \\
\text { [Rating] }\end{array}$} & $\begin{array}{c}\mathrm{Sf} \\
<5 \mathrm{~mm} \\
{[2]}\end{array}$ & $\begin{array}{c}\text { Sf } \\
<5 \mathrm{~mm} \\
{[2]}\end{array}$ & $\begin{array}{c}\text { Hd } \\
<5 \mathrm{~mm} \\
{[4]}\end{array}$ & $\begin{array}{l}\text { No } \\
{[6]}\end{array}$ & $\begin{array}{c}\text { Sf } \\
>5 \mathrm{~mm} \\
{[0]}\end{array}$ & $\begin{array}{c}\mathrm{Hd} \\
<5 \mathrm{~mm} \\
{[4]}\end{array}$ & $\begin{array}{c}\text { Sf } \\
<5 \mathrm{~mm} \\
{[2]}\end{array}$ & $\begin{array}{c}\text { Hd } \\
<5 \mathrm{~mm} \\
{[4]}\end{array}$ & $\begin{array}{c}\text { Sf } \\
<5 \mathrm{~mm} \\
{[2]}\end{array}$ & $\begin{array}{c}\mathrm{Hd} \\
>5 \mathrm{~mm} \\
{[2]}\end{array}$ & 9) \\
\hline & \multicolumn{2}{|c|}{$\begin{array}{l}\text { Weathering } \\
\text { [Rating] }\end{array}$} & $\begin{array}{c}\text { Fresh } \\
{[6]}\end{array}$ & $\begin{array}{l}\text { Slightly } \\
\text { [5] }\end{array}$ & $\begin{array}{c}\text { Md-Hw } \\
{[2]}\end{array}$ & $\begin{array}{c}\text { Fresh } \\
{[6]}\end{array}$ & $\begin{array}{c}\text { Fresh } \\
{[6]}\end{array}$ & $\begin{array}{c}\text { Fresh } \\
{[6]}\end{array}$ & $\begin{array}{l}\text { Md } \\
{[3]}\end{array}$ & $\begin{array}{c}\text { Fresh } \\
{[6]}\end{array}$ & $\begin{array}{c}\text { Slightly } \\
{[5]}\end{array}$ & $\begin{array}{c}\text { Slightly } \\
{[5]}\end{array}$ & \\
\hline \multirow{5}{*}{ कु } & \multirow{2}{*}{\multicolumn{2}{|c|}{$(\mathrm{Rr})$}} & 4 & 2 & 0 & 4 & 4 & 4 & 0 & 4 & 4 & 2 & Fror \\
\hline & & & 5 & 4 & 1 & 5 & 5 & 5 & 2 & 5 & 4 & 4 & Table of $B$ \\
\hline & \multicolumn{2}{|c|}{$\begin{array}{l}(R w) \\
(R f)\end{array}$} & 1 & 1 & 3 & 5 & 0 & 3 & 1 & 3 & 1 & 1 & $(19$ \\
\hline & \multicolumn{2}{|c|}{$(\mathrm{SCR})$} & 10 & 7 & 4 & 14 & 9 & 12 & 3 & 12 & 9 & 7 & $S C R=\Sigma R r+R w+R f$ \\
\hline & \multicolumn{2}{|c|}{ (SR) } & 70.70 & 56.94 & 52.97 & 77.84 & 73.63 & 77.74 & 50.65 & 74.30 & 74.39 & 61.95 & $\mathrm{SR}=100-17.5322 \mathrm{ln} \mathrm{nv}$ \\
\hline \multicolumn{3}{|c|}{ (GSI) } & 64.61 & 46.67 & 35 & 81.67 & 62.46 & 75.20 & 31.10 & 73 & 63.35 & 49.17 & From Table 4 \\
\hline \multirow{2}{*}{\multicolumn{3}{|c|}{$\frac{(\mathrm{Jv})\left(\mathrm{J} / \mathrm{m}^{3}\right)}{\text { Degree of Jointing }}$}} & 5.32 & 11.66 & 14.63 & 3.54 & 4.5 & 3.56 & 16.69 & 4.33 & 4.31 & 8.76 & From Table 2 \\
\hline & & & Md & High & High & Md & Md & Md & High & Md & Md & Md & Palmstrom (2005) \\
\hline \multicolumn{3}{|c|}{ RQD (\%) } & 96.70 & 80.86 & 73.44 & $100^{(1)}$ & 98.76 & $100^{(1)}$ & 68.28 & 99.18 & 99.23 & 88.10 & From Table 2 \\
\hline \multicolumn{3}{|c|}{ Classification based on GSI } & Good & Fair & Poor & V. Good & Good & Good & Poor & Good & Good & Fair & Bieniawski (1989) \\
\hline
\end{tabular}

Table 2 Volumetric joint count (Jv) and Rock Quality Designation (RQD) measurements from average spacings of the main joint sets measured on the rock surface exposures of Sabir granitic rock mass in Taiz city, Yemen

\begin{tabular}{|c|c|c|c|c|c|c|c|c|c|c|c|c|c|}
\hline \multicolumn{3}{|c|}{ Station No. } & 74 & 76 & 77 & 80 & 81 & 85 & 86 & 88 & 90 & 91 & Remarks \\
\hline \multirow{10}{*}{$\begin{array}{l}\text { Average set } \\
\text { spacing (s) of disc. } \\
\text { (joint) (m) and } \\
\text { Average frequency } \\
\text { (A. Fr.) }\end{array}$} & \multirow{2}{*}{\begin{tabular}{|c} 
Joint set1 \\
(J1)
\end{tabular}} & (S1) & 1.16 & 0.24 & 0.22 & 0.9 & 0.62 & 0.98 & 0.13 & 0.55 & 1.13 & 0.29 & Field measurements \\
\hline & & (A.Fr.) & 0.86 & 4.17 & 4.55 & 1.11 & 1.61 & 1.02 & 7.69 & 1.82 & 0.88 & 3.45 & A.Fr. $=1 /$ Average spacing \\
\hline & \multirow{2}{*}{\begin{tabular}{|c|} 
Joint set2 \\
(J2)
\end{tabular}} & $(\mathrm{S} 2)$ & 0.31 & 0.28 & 0.33 & 0.64 & 0.59 & 1.08 & 0.26 & 1.11 & 0.71 & 0.32 & Field measurements \\
\hline & & (A.Fr.) & 3.23 & 3.57 & 3.03 & 1.56 & 1.69 & 0.93 & 3.85 & 0.90 & 1.41 & 3.13 & A.Fr. : =1/Average spacing \\
\hline & \multirow{2}{*}{\begin{tabular}{|c|} 
Joint set3 \\
(J3)
\end{tabular}} & (S3) & 1.2 & 0.6 & 0.16 & 1.15 & 1.27 & 0.62 & 0.23 & 0.62 & 0.62 & 0.56 & Field measurements \\
\hline & & (A.Fr.) & 0.83 & 1.67 & 6.25 & 0.87 & 0.79 & 1.61 & 4.35 & 1.61 & 1.61 & 1.79 & A.Fr. : $=1 /$ Average spacing \\
\hline & \multirow{2}{*}{\begin{tabular}{|c} 
Joint set4 \\
(J4)
\end{tabular}} & (S4) & - & 0.54 & - & - & - & - & - & - & - & - & Field measurements \\
\hline & & (A.Fr.) & - & 1.85 & - & - & - & - & - & - & - & - & A.Fr. : $=1 /$ Average spacing \\
\hline & \multirow{2}{*}{$\operatorname{Rm}(S)$} & $(\mathrm{S})^{*}$ & 5 & 5 & 5 & - & 5 & - & 5 & - & 5 & 5 & Field observations \\
\hline & & (A.Fr.) & $2 / 5=0.4$ & $2 / 5=0.4$ & $4 / 5=0.8$ & - & $2 / 5=0.4$ & - & $4 / 5=0.8$ & - & $2 / 5=0.4$ & $2 / 5=0.4$ & \multirow{2}{*}{ Based on Equation (1) } \\
\hline \multicolumn{3}{|c|}{$\mathrm{Jv}\left(\mathrm{j} / \mathrm{m}^{\mathrm{s}}\right)$ (ave.) $=\sum$ frequencies (Fr.s) } & 5.32 & 11.66 & 14.63 & 3.54 & 4.5 & 3.56 & 16.69 & 4.33 & 4.31 & 8.76 & \\
\hline \multicolumn{3}{|c|}{ Rock Quality Designation (RQD) (\%) } & 96.70 & 80.86 & 73.44 & $100^{(1)}$ & 98.76 & $100^{(1)}$ & 68.28 & 99.18 & 99.23 & 88.10 & Based on Equation (2) \\
\hline \multicolumn{3}{|c|}{ Classification based on RQD $\%$} & Exc. & Good & Exc. & Exc. & Exc. & Exc. & Fair & Exc. & Exc. & Good & Deer, (1968) \\
\hline
\end{tabular}

Geomechanic classification system known as Rock Mass Rating (RMR) [23, 11] was employed in this study for geotechnical characterization of Sabir granitic rock masses in the field. The input basic parameters of Rock Mass Rating (RMR) [11] are six. They are: Uniaxial compressive strength of intact rock (UCS) (A1), Rock quality designation (RQD) (A2), Spacing of discontinuities (A3), condition of discontinuities (A4), groundwater condition (A5) and orientation of discontinuities (A6). These parameters (excluding the sixth parameter-A6) were obtained numerically/ descriptively for the various investigated zones. Only the first five parameters ratings (with no adjustment for discontinuity orientation) are calculated for basic RMRb89 (Table 3); based on the
Table given by Bieniawski [11]. Here, the accurate ratings of $\mathrm{A} 1$ (uniaxial compressive strength) and A2 (RQD) were determined using the charts suggested by Bieniawski [11] (Figs. 3a and 3b). These charts are helpful for borderline cases and also remove an impression that abrupt changes in ratings occur between categories. The sum ratings of five parameters $(\mathrm{A} 1+\mathrm{A} 2+\mathrm{A} 3+\mathrm{A} 4+\mathrm{A} 5)$ yield the RMR values (C: RMR) (Table 3).

The Geological Strength Index (GSI) system was also applied in this study for characterization of Tertiary granitic rock masses. A quantitative numerical basis to estimate more precise values was provided by Hamasur [24]. This quantitative rock mass classification was modified after [25, 26, $27 \& 28]$. 
Table 3 Calculation of the RMR parameters for the Sabir granitic rock mass in Taiz city, Yemen

\begin{tabular}{|c|c|c|c|c|c|c|c|c|c|c|c|c|c|c|c|}
\hline \multirow[b]{2}{*}{$\begin{array}{l}\text { St. } \\
\text { no. }\end{array}$} & \multirow{2}{*}{$\begin{array}{l}\text { Geotech- } \\
\text { nical sub- } \\
\text { unit }\end{array}$} & \multirow[b]{2}{*}{ Zone } & \multicolumn{2}{|c|}{ A1 } & \multicolumn{2}{|c|}{ A2 } & \multicolumn{2}{|c|}{ A3 } & \multicolumn{2}{|c|}{ A4 } & \multicolumn{2}{|c|}{ A5 } & \multicolumn{3}{|c|}{$\mathrm{C}: \mathrm{RMRb}_{\mathrm{g}}=\mathrm{A} 1+\mathrm{A} 2+\mathrm{A} 3+\mathrm{A} 4+\mathrm{A} 5$} \\
\hline & & & Values & Rating & Values & Rating & $\begin{array}{c}\text { Values } \\
(\mathrm{m})(\mathrm{min} .)\end{array}$ & Rating & Values & Rating & $\begin{array}{l}\text { Values } \\
\text { (desc.) }\end{array}$ & Rating & Rating & RMC & RMD \\
\hline 74 & \multirow{10}{*}{ 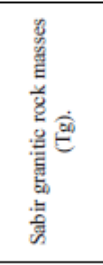 } & I & 96.16 & 9.2 & 96.7 & 19.3 & 0.31 & 10 & \multirow{10}{*}{ 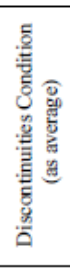 } & 18 & C. dry & 15 & 71.5 & II & Good \\
\hline 76 & & I & 47.66 & 5.4 & 80.86 & 15.8 & 0.24 & 10 & & 13 & C. dry & 15 & 59.2 & III & Fair \\
\hline 77 & & I & 31.44 & 3.8 & 73.44 & 14.4 & 0.16 & 8 & & 12 & C. dry & 15 & 53.2 & III & Fair \\
\hline 80 & & I & 47.04 & 5.3 & 100 & 20 & 0.64 & 15 & & 22 & C. dry & 15 & 77.3 & II & Good \\
\hline 81 & & I & 132.3 & 11.4 & 98.76 & 19.7 & 0.59 & 10 & & 16 & C. dry & 15 & 72.1 & II & Good \\
\hline 85 & & I & 149.1 & 12.3 & $100^{(1)}$ & 20 & 0.62 & 15 & & 18 & C. dry & 15 & 80.3 & II/I & Good/V.G \\
\hline 86 & & I & 18.94 & 2.8 & 68.28 & 13.6 & 0.13 & 8 & & 12 & C. dry & 15 & 51.4 & III & Fair \\
\hline 88 & & I & 34.06 & 4.1 & 99.18 & 19.8 & 0.55 & 10 & & 20 & C. dry & 15 & 68.9 & II & Good \\
\hline 90 & & I & 64.34 & 6.6 & 99.23 & 19.9 & 0.62 & 15 & & 16 & C. dry & 15 & 72.5 & II & Good \\
\hline 91 & & I & 52.92 & 5.8 & 88.1 & 17.6 & 0.29 & 10 & & 14 & C. dry & 15 & 62.4 & II & Good \\
\hline & Remarks & & 疍 & के & ํㅐㄹ & $\begin{array}{l}\text { क़ } \\
\text { है }\end{array}$ & 商 & 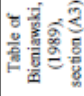 & 嘀 & 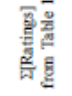 & 黄 & 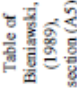 & 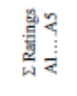 & $\begin{array}{r}\text { Bieni: } \\
\text { se }\end{array}$ & $\begin{array}{l}\text { Table of } \\
\text { ki, (1989), } \\
\text { on (C) }\end{array}$ \\
\hline
\end{tabular}

RMRbiv $=$ Basic RMR, with no adjusting factor for joint orientation, St. no: Station number. Al:ratings for the uniaxial compressive strength of the intact material(MPa), A2: ratings for the Rock Quality
Designation (RQD \%), A3: ratings for the spacing of discontinuities (average minimum spacing is taken from Table 4.16, accord ing to Edelloro (2003). A4:ratings for the condition of discontinuities obtained from Table of Bieniawski (1989) A5: ratings for the groundwater condition, C.dry: Couppletely dry. (desc): descriptive term. C: Rock mass rating demined from total ratings, RMC: Rock mass class, RMD: from Table of Buentawski, (1989), A5: ratings for the groundwater condition, C. diry: Completely dry. (d.sce)

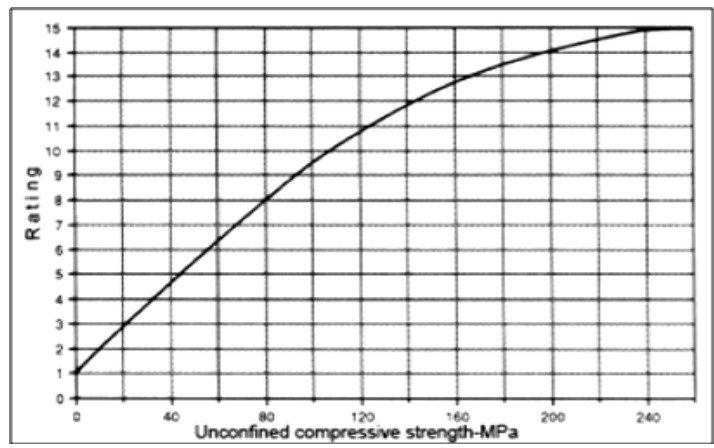

Figure 3a Variation of rating for the Uniaxial Compressive Strength (after Bieniawski, 1989)

The main components of this modified quantitative rock mass classification are the structure rating (SR) and surface condition rating (SCR). The structure rating (SR) is determined from volumetric joint count (Jv) and according to the following Equation:

$$
\mathrm{SR}=100-17.5322 \ln \mathrm{Jv} \quad \ldots \ldots \ldots \ldots \ldots
$$

where $\mathrm{Jv}$ is volumetric joint count $\left(\mathrm{J} / \mathrm{m}^{3}\right)$.

Surface condition rating (SCR) is estimated from sum of the roughness $(\mathrm{Rr})$, weathering $(\mathrm{Rw})$ and infilling (Rf) materials ratings; which are assessed visually in the field. Because the GSI is based on the $\mathrm{RMR}_{76}$ [25], the roughness, weathering and infilling ratings (SCR) are also based on the RMR76, in which the sum of these three parameters ranges from 0 to 15 [24]. The intersection of these ratings (SCR and SR) on the modified quantitative GSI chart gives precise value of GSI (Table 4). The derived values from the GSI chart for the various investigated sites are shown in the Table 1. Finally, at representative sites, rock block samples also were selected for the geotechnical laboratory tests.

\subsection{Laboratory Procedures}

The physical characteristics of the Tertiary granitic rocks were determined in the laboratory on rock specimens prepared from rock block samples collected from the investigated representative sites.

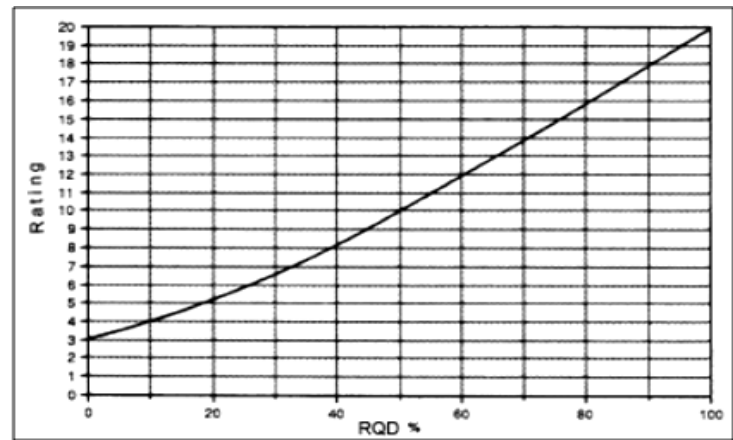

Figure 3b Variation of rating for the RQD (after Bieniawski, 1989)

Determination of water content (Wc), unit weight $(\gamma)$, dry density $\left(\rho_{d}\right)$, porosity, water absorption (W. $\mathrm{Ab}$ ), bulk specific gravity (Gs) and apparent specific gravity (A.Gs) were made according to the methods suggested by the ISRM [29]. The results of all the physical properties of granitic rock samples are provided in Table 5. The mechanical characteristics include uniaxial compressive strength (UCS), Point load test (PLT) and Schmidt Hammer rebound test, (SH) (in the field and lab.). These tests were performed as per the procedures provided by many researchers and organizations [13, 30, 31, 32 \& 33]. All these geotechnical tests were performed in the materials laboratory of Sheba General Contracting Co. Ltd, main branch, Taiz, and in Technical institute, Al-Hassib, Taiz, Yemen.

The point load strength (PLS) test was used as cheaper and effective alternative to the UCS test when the rock specimen for UCS tests could not be obtained from rock exposures. This test was carried out on geometrical form rock samples (regular specimens) and/or irregular lumps in the laboratory and according to Brook [32] and ISRM [33]. The following relationship between the PLS and UCS and suggested by Rusnak and Mark [34] was used:

$\mathrm{UCS}=21{ }^{*}$ Is $_{(50)} \ldots \ldots \ldots \ldots$ (4), where Is ${ }_{(50)}$ is Point load strength index of a specimen of $50 \mathrm{~mm}$ diameter. 
Table 4 Plot of the GSI values based on SR and SCR ratings for Sabir granitic rock mass, Taiz city, Yemen

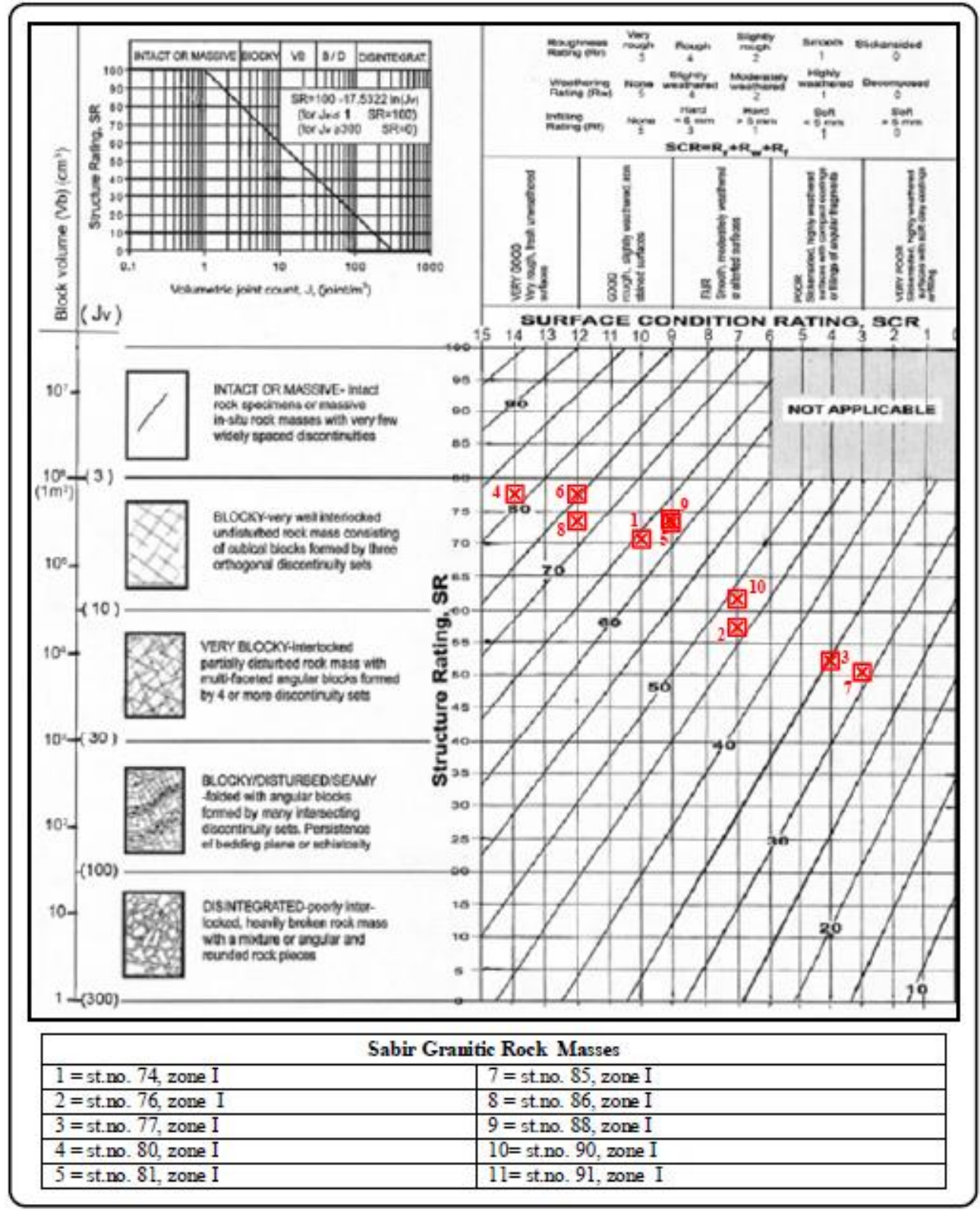

Schmidt hammer tests using an N-type hammer were undertaken on some of exposed rock faces (7 zones) as suggested by Barton and Choubey [31].

The $\mathrm{N}$ - type rebound data obtained were converted to L- type data using the following empirical correlation developed by Ayday and Grktan [35]:

$\operatorname{Rn} \quad(\mathrm{N})=7.124+1.249 \mathrm{Rn} \quad(\mathrm{L}), \quad\left(\mathrm{r}^{2}=0.882\right)$ ............ (5), where $\mathrm{Rn}(\mathrm{L})$ and $\mathrm{Rn}(\mathrm{N})$ are respectively the L-type and N-type Schmidt hammer rebound numbers; and $\mathrm{r}^{2}$ is the determination coefficient.

To get Schmidt hammer rebound number, initially ten impact readings were undertaken in each case, and the average of the 5 highest readings taken to represent a mean rebound value (r) [13]. Conversion to equivalent uniaxial compressive strength values was undertaken using the equation and chart of Miller presented by Deere and Miller [36].The study of the physico-mechanical properties of the Tertiary granitic rock masses is based on the block samples weighting between 30 to $50 \mathrm{~kg}$ and with a minimum thickness of $10 \mathrm{~cm}$ to allow cubing of samples. On pieces of these block samples; the physical characteristic tests were performed in the laboratory. Before tests, the rock samples prepared as definite geometrical forms were immersed in water for 48 hours for the purpose of testing their strengths in the worst situation. The results of the all mechanical properties of granitic rock samples are provided in Table5. 
Table 5 Laboratory test results of the physico-mechanical characteristics of intact rock samples of Sabir granitic rock mass $(\mathrm{Tg})$ in the study area

\begin{tabular}{|c|c|c|c|}
\hline Characteristic & Property & Results & $\begin{array}{c}\text { No. of Tests } \\
(\mathrm{N} / \mathrm{Ft})\end{array}$ \\
\hline \multirow{7}{*}{$\begin{array}{l}\text { Physical } \\
\text { characteristics }\end{array}$} & Range /(ave.) of Wc \% & $0.269-0.91 /(0.628)$ & $\mathrm{N}=9$ \\
\hline & Range /(ave.) of ( $\gamma)\left(\mathrm{KN} / \mathrm{m}^{3}\right)$ & $23.806-26.117 /(24.827)$ & $\mathrm{N}=9$ \\
\hline & Range of ave.pd $\left(\mathrm{gm} / \mathrm{cm}^{3}\right)$ & $2.415-2.656$ & \multirow{5}{*}{$\mathrm{N}=75$} \\
\hline & Range of ave. $n(\%)$ & $2.099-6.976$ & \\
\hline & Range of ave.W.Ab. (\%) & $0.792-3.123$ & \\
\hline & Range of ave.Gs (Ssd) & $2.484-2.677$ & \\
\hline & Range of ave. A. Gs & $2.589-2.713$ & \\
\hline \multirow{4}{*}{$\begin{array}{l}\text { Mechanical } \\
\text { characteristics }\end{array}$} & $\sigma_{\mathrm{ci}}(\mathrm{UCS}$ ) (in lab.) (MPa), range /(ave.) & $12.12-74.57 /(35.892)$ & $\mathrm{N}=13$ \\
\hline & $\sigma_{c i}(\mathrm{PLT})(\mathrm{MPa})$, range $/($ ave $)$ & $52.92-184.8 /(122.14)$ & $\mathrm{N}=7$ \\
\hline & $\sigma_{c i}(\mathrm{SH})(\mathrm{MPa})$, in field, (range /(ave.)) & $27.3-45.2 /(35.21)$ & $\mathrm{Ft}=7$ \\
\hline & A verage of $\sigma_{\mathrm{ci}}(\mathrm{UCS})(\mathrm{MPa})$ (as range)* & $25.71-119.38$ & $\mathrm{~N}+\mathrm{Ft}=27$ \\
\hline
\end{tabular}

Where: Wc: Water content, ave: average, $\gamma$ : Unit weight, od: Dry density, $\mathrm{n}$ : Porosity, W. Ab.: Water Absorption Gs(Ssd): Bulk Specific gravity (Saturated-surface-dry mass), A.Gs = Apparent Specific gravity, UCS: Uniaxial compressive test in the laboratory conditions, PLT: Point Load Test, SH: Schmidt Hammer, GH: Geological Hammer, the ranges of averaged results from all strength tests, N: number of the tested specimens, Ft: Number of field tests.

Based on the field measurements and laboratory tests data, the generalized Hoek-Brown failure criterion [37] is applied for estimating the strength and deformability of the Tertiary jointed granitic rock masses, employing RocLab software program [38]. In applying the Hoek and Brown criterion to achieve this task, three parameters are required (as input parameters). These are: uniaxial compressive strength $\left(\sigma_{\mathrm{ci}}\right)$ of the intact rock pieces, value of the Hoek-Brown constant (mi) for these intact rock pieces, and value of the Geological Strength Index (GSI). The $\sigma_{\mathrm{ci}}$ is obtained from laboratory and/or field tests. The quantified geological strength index (GSI) values were obtained as mentioned before. The intact rock constant (mi) was estimated according to rock type and then quoted from the Table proposed by Hoek and Brown [39] and Hoek [40]. Accordingly, the intact granitic constant (mi) is 32. The disturbance factor (D) which depends upon amount of stress relaxation, weathering, and blast damage associated with the method of excavation has been taken into account in the 2002 version of the Hoek-Brown criterion. The value of $\mathrm{D}$ ranges from 0 to 1 and represents a progressive transition between the criteria for disturbed and undisturbed rock masses. Here, based on the guidelines recommended by [37, 40], the estimated D values used in generalized Hoek- Brown failure criterion are 0 (undisturbed in situ rock masses), 0.7 (partially disturbed in situ rock masses) and 1 (highly disturbed in situ rock masses). Also the intact rock deformation modulus (Ei) is required as input value for the determination of the rock mass deformation modulus. In this study, no direct value of the intact modulus (Ei) is available so this value was also estimated using average values of modulus ratio MR of intact rock which are obtained from the Table modified by Hoek and Diederichs [41], based on Deere [42] and Palmstrom and Singh [43]. Accordingly the MR value for intact granite is 425. This value was entered into RocLab software program (2013) for the calculation of the rock modulus of elasticity (Ei).

Table 6 Input data used in RocLab software for the determination of rock mass parameters for Sabir granitic rock mass in the study area

\begin{tabular}{|l|c|c|c|c|c|c|}
\hline $\begin{array}{l}\text { Geotechnical sub-unit and } \\
\text { abbreviation }\end{array}$ & $\begin{array}{c}\text { No. investigated } \\
\text { zones }\end{array}$ & $\sigma_{\mathrm{ci}}$ (MPa) & GSI & mi & D & MR \\
\hline Sabir granitic rock mass (Tg) & 10 & From Table (3) & $\begin{array}{c}\text { From } \\
\text { Table (1) }\end{array}$ & 32 & $\begin{array}{c}0 \\
0.7 \\
1\end{array}$ & \begin{tabular}{c} 
(425) \\
\hline
\end{tabular} \\
\hline
\end{tabular}

Where:, $\sigma_{\mathrm{i} i}(\mathrm{MPa})$ : Uniaxial compressive strength (UCS) of intact rock, GSI: Geological Strength Index obtained as precise values, $\mathrm{mi}=$ Intact rock constant estimated according to rock type ( Hoek and Brown,1997 and Hoek, 2007), Average MR value is 425 (Hoek and Diederichs, 2006, based on Deere, 1968 and Palmstrom and Singh 2001), D disturbance factor; here, $D=0$ for undisturbed in situ rock mass, 0.7 for partially disturbed in situ rock mass, and 1 for highly disturbed in situ rock mass, based on Hoek, et al (2002) and Hoek (2007). 
The parameters (input parameters; $\sigma c i, \mathrm{GSI}$, mi, D and MR) (Table 6) related to granite geotechnical unit were entered into RocLab software to compute the values of the rock mass properties (c, $\varnothing, \sigma_{\mathrm{tm}}, \sigma_{\mathrm{c}}, \sigma_{\mathrm{cm}}$ and $\mathrm{E}_{\mathrm{rm}}$ ) (as output parameters) (Table $7)$.

Table 7 Results of the estimated Sabir granitic rock mass properties in the study area following the GH-B failure criterion

\begin{tabular}{|c|c|c|c|c|c|c|c|c|c|c|c|}
\hline \multirow{2}{*}{$\begin{array}{l}\text { St. } \\
\text { No. }\end{array}$} & \multirow{2}{*}{$\begin{array}{l}\text { Geotech- } \\
\text { nical } \\
\text { sub-unit }\end{array}$} & \multirow{2}{*}{ Zone } & \multicolumn{3}{|c|}{$\begin{array}{l}\text { Hoek-Brown } \\
\text { classification }\end{array}$} & \multicolumn{2}{|c|}{$\begin{array}{l}\text { Mohr-Coulomb } \\
\text { fit }\end{array}$} & \multicolumn{4}{|c|}{ Rock mass parameters(MPa) } \\
\hline & & & $\mathrm{mb}$ & s & a & $\begin{array}{c}\mathrm{C} \\
(\mathrm{MPa})\end{array}$ & $\begin{array}{c}\varnothing \\
\text { (deg) }\end{array}$ & $\sigma_{m}$ & $\sigma_{e}$ & $\sigma_{c m}$ & $E_{m m}$ \\
\hline 74 & \multirow{10}{*}{$\begin{array}{c}\text { Sabir } \\
\text { granitic } \\
\text { rock } \\
\text { mass } \\
(\mathrm{Tg})\end{array}$} & $\mathrm{I}$ & 9.041 & 0.0196 & 0.502 & 5.901 & 44.927 & -0.15 & 9.605 & 28.441 & 18319.6 \\
\hline 76 & & $\mathrm{I}$ & 1.708 & 0.0004 & 0.507 & 2.305 & 30.741 & -0.012 & 0.945 & 8.104 & 1758.74 \\
\hline 77 & & I & 0.9 & 0.0008 & 0.516 & 1.169 & 25.411 & -0.003 & 0.244 & 3.7 & 598.6 \\
\hline 80 & & $\mathrm{I}$ & 11.689 & 0.0702 & 0.501 & 4.582 & 46.898 & -0.282 & 12.446 & 23.206 & 9939.14 \\
\hline 81 & & $\mathrm{I}$ & 4.068 & 0.0043 & 0.502 & 8.718 & 38.127 & -0.141 & 8.6 & 35.851 & 13002.4 \\
\hline 85 & & $\mathrm{I}$ & 13.197 & 0.0636 & 0.501 & 14.786 & 47.949 & -0.718 & 37.501 & 76.935 & 51915.9 \\
\hline 86 & & $\mathrm{I}$ & 0.233 & 0.00001 & 0.521 & 0.409 & 15.702 & -0.0008 & 0.048 & 1.079 & 234.03 \\
\hline 88 & & I & 7.259 & 0.02 & 0.501 & 2.757 & 43.02 & -0.094 & 4.8 & 12.688 & 5532.9 \\
\hline 90 & & $\mathrm{I}$ & 2.335 & 0.0022 & 0.502 & 3.551 & 33.352 & -0.061 & 2.993 & 13.178 & 4067.3 \\
\hline 91 & & I & 1.96 & 0.0006 & 0.506 & 2.693 & 31.901 & -0.017 & 1.272 & 9.698 & 2288.15 \\
\hline
\end{tabular}

GH-B: Generalized Hoek-Brown failure criterion, mi, $\mathrm{mb}$, s and a $=$ Material Constants, $\mathrm{C}$ and $\varnothing=$ Cohesion (MPa) and Friction Angle (deg.) respectively, $\sigma_{\mathrm{mm}}=$ Tensile Strength $(\mathrm{MPa}), \sigma_{c}=\mathrm{Uniaxial}$ Compressive Strength $(\mathrm{MPa}), \sigma_{\mathrm{cm}}=$ Global Strength $(\mathrm{MPa}), \mathrm{E}_{\mathrm{mm}}=$ Deformation Modulus.

\section{RESULTS AND DISCUSSION}

3.1 Geotechnical characterization of Sabir granitic rock masses $(\mathbf{T g})$

The geomechanical behavior of rock mass is governed by characteristics of both intact rock material and discontinuities crossed the rock masses.

\subsubsection{Characteristics of Intact Rock Material}

The physical tests carried out for granitic rock samples involve the determination of water content $(\%)$, unit weight $(\gamma)\left(\mathrm{KN} / \mathrm{m}^{3}\right)$, dry density $\left(\rho_{\mathrm{d}}\right.$ $\mathrm{g} / \mathrm{cm}^{3}$ ), porosity (n \%), water absorption (W. Ab \%), bulk specific gravity (Gs) and apparent specific gravity (A.Gs). The ranges of average values of these properties are presented in Table 5. The values of water content and unit weights range from 0.269 to $0.91 \%$ and from 23.806 to $26.117 \mathrm{KN} / \mathrm{m}^{3}$ respectively. The ranges of average minimum and maximum values of other five parameters are 2.415$2.656 \mathrm{~g} / \mathrm{cm}^{3}, 2.099-6.976 \%, 0.792-3.123 \%, 2.484-$ 2.677 and $2.589-2.713$ respectively. According to the obtained values of dry density, porosity and water absorption, the granitic rocks belong to the class of "Moderate to High" density "Low to Medium" porosity [44] and "Good to Marginal" water absorption respectively [45]. The strength values obtained from the uniaxial compressive strength (UCS-lab) and point load (PLT-lab) tests vary from 2.12 MPa to $74.57 \mathrm{MPa}$ and from 52.92 $\mathrm{MPa}$ to $184.84 \mathrm{MPa}$ respectively while the rock strength obtained from Schmidt hammer (SH-in field) tests range between $27.3 \mathrm{MPa}$ and $45.2 \mathrm{MPa}$ with an average of $35.21 \mathrm{MPa}$ (Table 5). The average values from all strength tests vary from $25.71 \mathrm{MPa}$ to $119.38 \mathrm{MPa}$ indicating that Sabir granitic rock masses are "Medium Strong" to "Very Strong"

\section{1.2 Discontinuities Characteristics of Sabir Granitic Rock Masses (Tg)}

Ten representative field stations of granitic outcrops were studied for the purpose of characterization of discontinuities (totally 305) and geotechnical classification of these rock masses. The surveys were carried out as detailed in the methodology section. Stereographically, three main sets of discontinuities are identified at each station; however, the fourth joint set occurs, in addition to random joint sets (Fig.4 \& Table 1). Figure 5 shows the variation in the strike directions of discontinuities which are predominately NE-SW and NW-SE running parallel to the strike directions of regional structures or faults. The averages of spacing of discontinuities vary from $0.13 \mathrm{~m}$ (close spacing) to $1.27 \mathrm{~m}$ (wide spacing). The averages of spacing which range from $0.22 \mathrm{~m}$ to $0.6 \mathrm{~m}$ and from $0.62 \mathrm{~m}$ to $1.27 \mathrm{~m}$ more frequency indicate "Moderate" to "Wide" spacing respectively [13]. These spacing would provide in-situ block size distribution that can give commercial value [46]. 
The discontinuity persistence varies from < $1 \mathrm{~m}$ to more $20 \mathrm{~m}$ ("Very Low" to "Very High" persistence). The surfaces of joints are generally rough, fresh to slightly and moderately weathered. Highly weathered surfaces stained with iron oxides, and dry surfaces with no evidence of water flow are also encountered. The width of the aperture varies from $1 \mathrm{~mm}$ (Open) to more than $5 \mathrm{~mm}$ (Moderately Wide). The joints are either open with no infilling or filled with hard or soft materials of varying thickness.

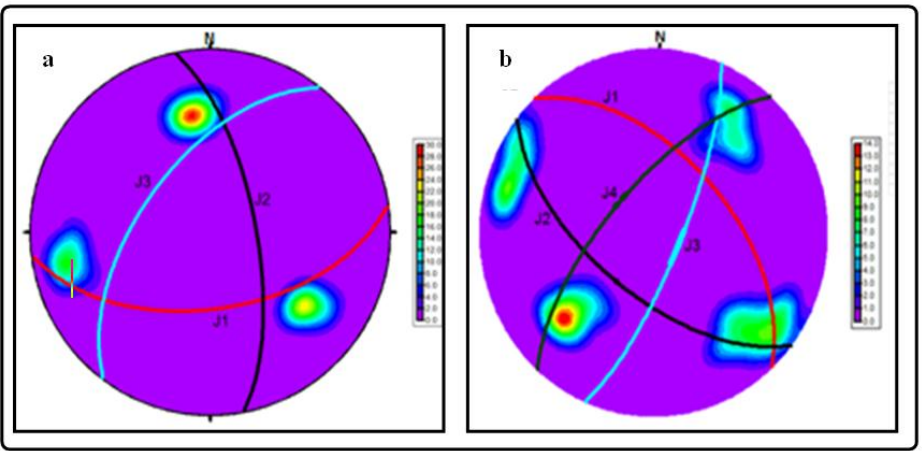

Figure 4 Two examples for equal- area stereographic projection of the main joint/ discontinuity sets in Tertiary Sabir granitic rock mass (Tg); a) Three joint sets at station No. 80; three sets are almost diagonal, b) Four joint sets at station No. 76; all sets also are almost diagonal

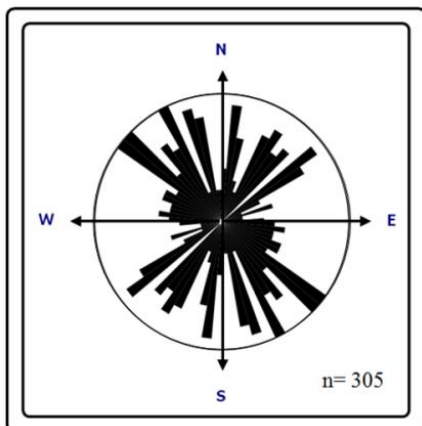

Figure 5 Rose Diagram showing the local variations in the strike directions of surveyed joints in the different stations of the Tertiary Sabir granitic rock mass $(\mathrm{Tg})$

\subsection{Geotechnical Classification of Sabir Granitic Rock Masses (Tg)}

Geotechnical classification of the granitic rock masses was carried out according to RQD, RMR and GSI and details of which are provided below.

\subsubsection{Rock Quality Designation (RQD) index}

For assessing rock quality quantitatively, Rock Quality Designation (RQD) index calculated from Jv was used (Table 2). The RQD values of granite range from $68.28 \%$ to $100 \%$ indicating "Fair to Excellent" quality rock class, with an average of $90.46 \%$ corresponding to "Good/ Excellent" quality rocks [42], however; the "Poor" and "Very Poor" rock qualities were also observed in the field (Fig. 6).

\subsubsection{Rock Mass Rating (RMR)}

The basic $\mathrm{RMR}_{89}$ rating values for the Sabir granitic rock mass vary from 51.4 to 80.3 indicating "Fair" to "Good/Very Good" quality rocks and belong to classes III and II of Bieniawski $[23,11]$. The basic $\mathrm{RMR}_{\mathrm{b} 89}$ values suggest that $30 \%$ of the rock belongs to "Fair" class and the remaining $70 \%$ of the granite belongs to "Good/Very Good" class of rocks (Table 3), however, the poor and very poor rock qualities were also observed in the field (Fig. 6).

\subsubsection{Geological Strength Index (GSI)}

The average values and ratings of the parameters required for the calculation of SR and SCR components and for the estimation of the quantified GSI values of the granitic rock masses are 
provided in the Table 1 . The obtained values of SR and SCR were plotted on GIS chart (Table 4) to derive GSI values. The obtained GSI values range from 31.1 to 81.67 (poor to very good) with an average of 58.22 (Table 1). The GSI values for the rocks showing "Blocky (B)" structure vary from 62.46 to 81.67 with an average of 67.07 and for "Very Blocky (VB)" structure, the values range from 31.1 to 46.67 with an average of 37.59 .

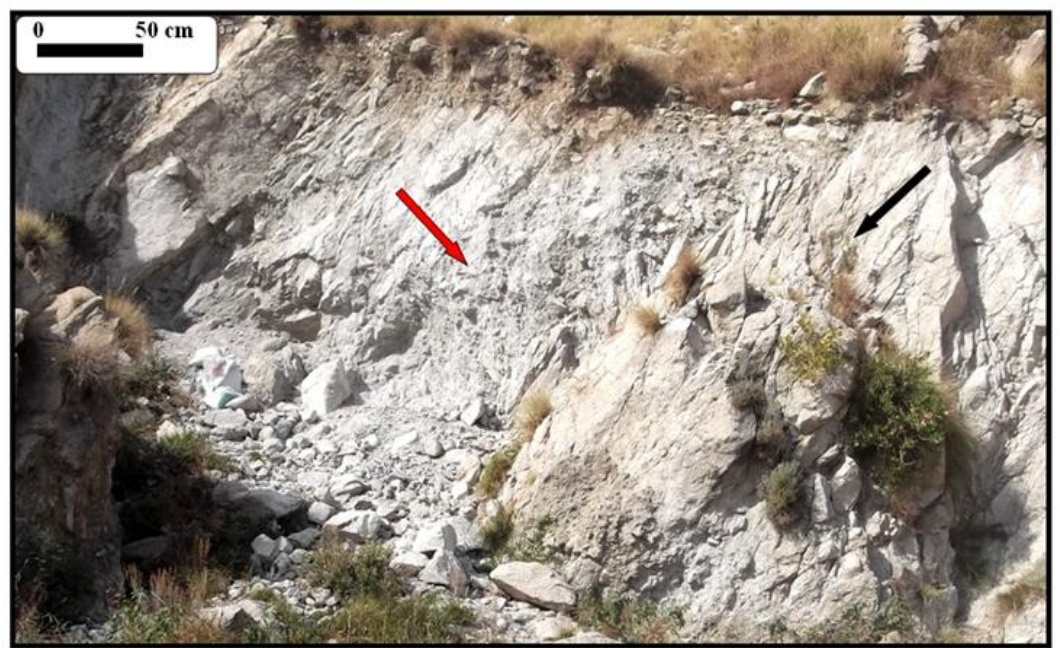

Figure 6 Field Photograph of high to moderately weathered Sabir granitic rock masses exposed to the east of Dar Al-Nasr, Sabir area; where quality of rock masses are poor (black arrow) and very poor (red arrow)

\subsection{Indirect Estimation of the Sabir Granitic Rock Masses Properties}

The strength and deformability of the Tertiary jointed Sabir granitic rock masses were estimated based on the generalized Hoek-Brown failure criterion [37] and Geological Strength Index (GSI) and employing RocLab software program (Rocscience, 2013). The input parameters required in this program for calculation of rock mass parameters for each granitic station are shown in Table 6.The obtained output parameters (Table 7) include: Hoek-brown classification parameters (mb,
$\mathrm{S}$ and a), Mohr-Coulomb Fit (shear strength parameters; $c, \varnothing)$ and rock mass parameters given in terms of compressive strength $\left(\sigma_{\mathrm{c}}\right)$, tensile strength $\left(\sigma_{\mathrm{tm}}\right)$, deformation modulus $\left(\mathrm{E}_{\mathrm{rm}}\right)$ and global strength $\left(\sigma_{\mathrm{cm}}\right)$. The averages of the obtained values of $\mathrm{mb}, \mathrm{s}$, a, c, $\varphi, \sigma_{\mathrm{c}}, \sigma_{\mathrm{tm}}, \mathrm{E}_{\mathrm{rm}}$ and $\sigma_{\mathrm{cm}}$ for Sabir granitic rock masses are: $5.239,0.0182,0.506,4.69 \mathrm{MPa}, 35.80^{\circ}$, -0.148 MPa, 7.85 MPa, 21.29 MPa and 10765.68 MPa respectively (Table 7). Note that the RMR value and the strength of intact rock sample are function of these properties as shown in the Figures $7 \mathrm{a}$ and $7 \mathrm{~b}$.

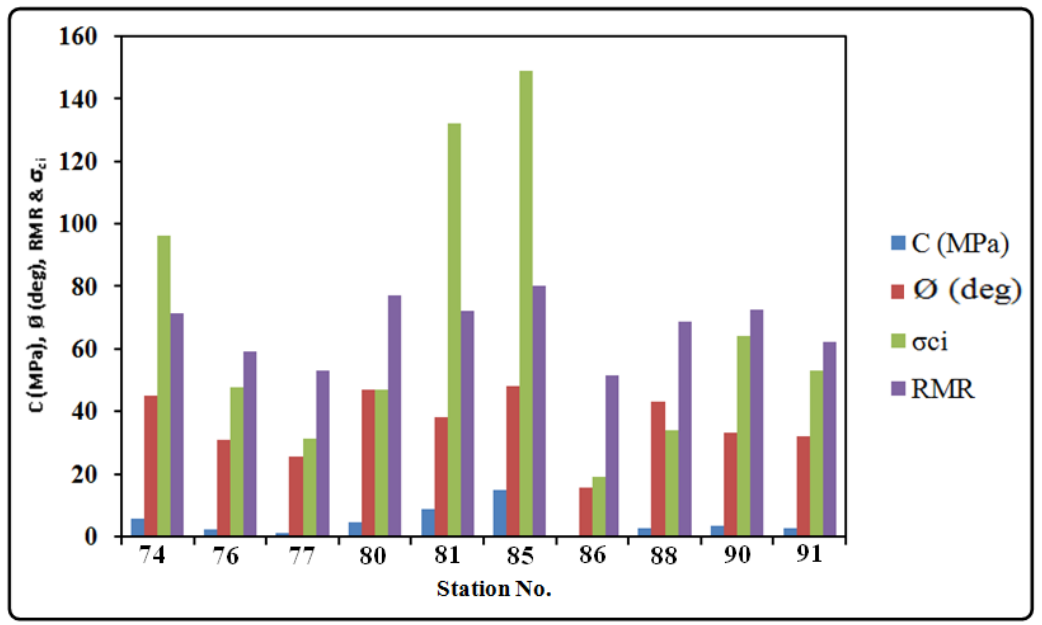

Figure7a Shows the proportional increase for strength parameters $(C, \varnothing)$ with that of RMR ratings of granitic rock mass and the strength values of intact rock granitic material; UCS $\left(\sigma_{\mathrm{ci}}\right)(\mathrm{MPa})$ at the different investigated granite stations 


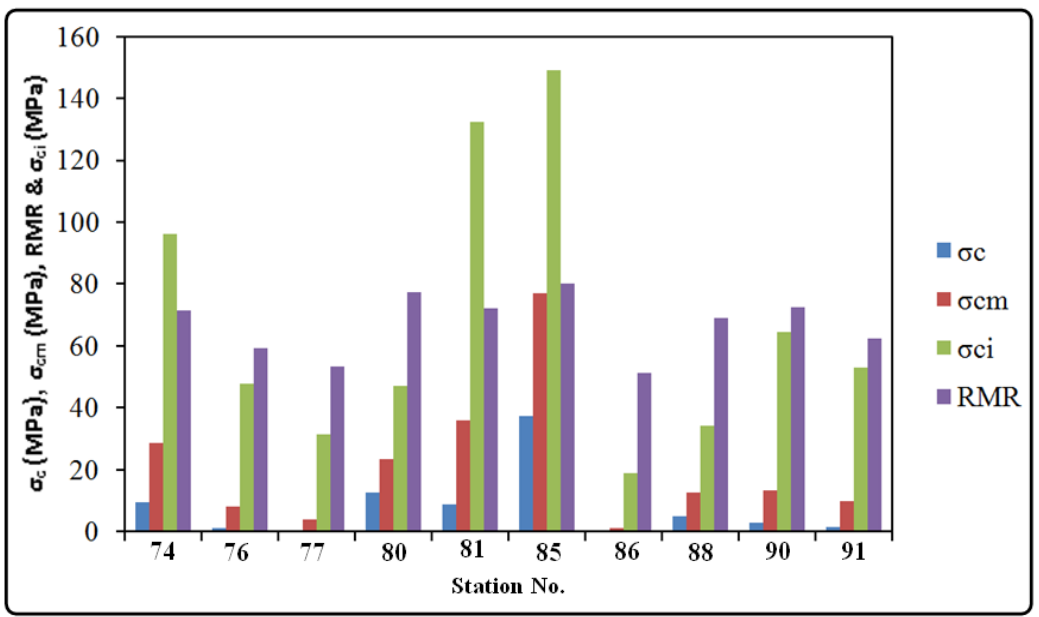

Figure7b Shows the proportional increase of the UCS $\left(\sigma_{\mathrm{c}}\right)(\mathrm{MPa})$ and Global strength $\left(\sigma_{\mathrm{cm}}\right)(\mathrm{MPa})$ values of rock masses with that of the UCS $(\mathrm{MPa})$ of intact granitic rock material $\left(\sigma_{\mathrm{ci}}\right)$ and RMR ratings for granitic rock masses at the different investigated granite stations

\section{CONCLUSIONS}

The present study, first of its kind in the study area, deals with characterization and evaluation of geo-engineering parameters of Tertiary granitic rock masses by direct and indirect methods. The direct approach includes the field measurements and tests (at 10 representative field stations) and the laboratory tests of phyisco-mechanical characteristics for samples collected from different field stations. Indirect approach for rock mass characterization is through two rock mass classification systems, namely Rock Mass Rating (RMR) and Geological Strength Index (GSI). The data obtained on Sabir granitic rock materials from laboratory and field investigations demonstrate that the geomechanical characteristics and behavior markedly vary between the rock masses of volcanic and non-volcanic origins which may be attributed to their volcanic nature, petrographic variety and structural complexity. The Tertiary granitic rock masses are found to be affected by the development of the intense fracturing systems which can pose instability problems when excavation for road cuts or construction purpose is made.

The phyisco-mechanical characteristics of these rocks showed range of variations in their dry densities, porosities, water absorption tendencies, bulk and apparent specific gravities and uniaxial compressive strengths (UCS) as the rocks contain microfractures and are affected by various degree of weathering and alteration. The UCS of these rocks are expected to be more because the tests were carried out on submerged rock samples in water for 24 hours (so they may lose their strength by average of $30 \%$ ). The lower strength ranges from Schmidt hammer $(\mathrm{SH})$ compared with strength ranges taken by PLT for these rocks probably reflect the sensitivity of the Schmidt hammer to surface alteration of the materials in the field and size of the rock sample in the laboratory. According to the obtained values of dry density, porosity and water absorption, the granitic rocks belong to the class of "Moderate" to "High" density, "Low" to "Medium" porosity. The average values from all strength tests vary from $25.71 \mathrm{MPa}$ to $119.38 \mathrm{MPa}$ indicating that Sabir granitic rock masses are "Medium Strong" to "Very Strong".

The characterization of the geotechnical granitic rock masses based on RQD, $\mathrm{RMRb}_{89}$ and GSI systems showed that these rocks have range of variations in their qualities and they are categorized as "Fair" to "Excellent" quality, "Fair" to "Good/Very Good" quality and "Poor" to "Very Good" quality classes. Values of shear strength parameters (c and $\varnothing$ ) and the other rock mass parameters $\left(\sigma_{\mathrm{tm}}, \sigma_{\mathrm{c}}, \sigma_{\mathrm{cm}}\right.$ and $\left.\mathrm{E}_{\mathrm{rm}}\right)$ of these rocks are varied, depending on rock mass quality and properties of intact rock. In general, the values of the rock mass parameters increase with increase in the quality of rock mass and intact rock properties.

The modified quantitative GSI system applied here has provided useful information about rock mass characteristics and can be used at all stages of any engineering project, especially at the preliminary design stage where only limited information is available.

\section{ACKNOWLEDGMENT}

The authors are deeply grateful to the manager of Sheba General Contracting Co. Ltd, main branch, Taiz and its technical staff at the materials laboratory as well as to technical staff at Technical institute, AlHassib, Taiz, Yemen who gave us the opportunity to carry out physical-mechanical tests. 


\section{REFERENCES}

[1] Refaat, A.M., El-Odylia and Kabesh, M.L. The Chemistry of Arfvedsonites and Riebeckites from Sabir alkali granites, Taiz area, Yemen Arab Republic. Chem. Erde. 39, 1980, 37-45.

[2] Shaalan, M.M.B. and Zalata, A.A. Petrography of the Tertiary Alkaline Granite of Gabal Sabir and the Associated Dykes, Y.A.R. [Z]. Geol. Soc. of Egypt $21^{\text {st }}$ Annual Meeting, 1983, (Abstract).

[3] Youssef, M., El-Shatoury, H. and Al-Kadasi, M." Geology of Gabal Saber Granitic Mass, Taizz, Yemen Republic" in Geology of The Arab World Conf., 1: 433-447, 1992, Cairo University, Egypt.

[4] Al-Kadasi, M. Geology of Gabal Saber granitic mass. Unpublished M. Sc. Thesis, Sana, a University, Yemen, 1988.

[5] El-Gharbawy, R., I. Petrogenesis of granitic rocks of the Jabal Sabir area, South Taiz City, Yemen Republic. Chin.J.Geochem, CAS and Springer-Verlag Berlin Heidelberg 30, 2011, 193-203.

[6] Al-Qadhi, A. A. D. Geoengineering Characterization of Rock Masses in and around Taiz City, Yemen. Unpublished Ph.D. Thesis, Mysore University, Mysore, India, 2017.

[7] Kruck, W., \& Schaffer, U. Geological map of Republic of Yemen (ROY). Scale 1:250,000 Taiz sheet. Minestry of Oil and Mineral Resources, Sana'a, Yemen, Fedral Institute of Geosciences and Natural Resources, Hanover (FRG), 1991.

[8] DEY and UN/DDSMS. Geological map. Hydrological and land-use studies in the upper Wadi Rasyan catchment. (TCD CONTARCT NO: YEM/93/010-3) map300. Scale 1:50,000, 1997.

[9] Malek, A. M., Janardhana, M. R., and AlQadhi, A. A. D. Cenozoic eruptive stratigraphy and structure in Taiz area of Yemen. Earth Sciences, Science publishing group, USA, Vol.3 (3), 2014, pp.85-96.

[10] Al-Qadhi, A. A. D., Janardhana, M.R., and Prakash, K.N. Field Occurrence and Petrographic Characteristics of Tertiary Volcanic Rocks and Associated Intrusions in and around Taiz City, Yemen. Inter. J. of
Advanced Earth Sci. and Eng., Vol. 5 (1), 2016, pp. 390-429.

[11] Bieniawski, Z.T. Engineering rock mass classification. John Wiley, New York, 1989.

[12] Brady B. H. G. and Brown E. T. Rock Mechanics for Underground Mining. George Allen \& Unwin, London, 1985.

[13] ISRM, Commission on Standardization of Laboratory and Field Test. Suggested Methods for the Rock Characterization, Testing and Monitoring. International Society for Rock Mechanics. E.T. Brown (editor), Pergamon Press, Oxford, UK, 1981a.

[14] RockWare, RockWorks/14. RockWare Incorporated, Golden, CO, 2008.

[15] Edelbro, C. Rock mass strength- a review. Technical Report, Lulea University of Technology, 2003, 132p.

[16] Palmstrom, A.The volumetric joint count - a useful and simple measure of the degree of jointing. Proc. 4th Int. Congr. IAEG, New Delhi, 1982, pp.v.221-v.228.

[17] [17]Palmstrom, A. Application of the Volumetric Joint Count as a Measure of Rock Mass Jointing. Proc.Int. SVmp. On Fundamentals of Rock Joints, Bjorkliden, Sweden, 1985, pp.103-110.

[18] Palmstrom, A. A General Practical Method for Identification of Rock Masses to be Applied in Evaluation of Rock Mass Stability Conditions and TBM Boring Progress. Proc. Conf. on Fjell sprengingsteknikk, Bergmekanikk. Geoteknikk, Oslo, Norway, 1986, pp.31.1-31.31.

[19] Sen Z., Eissa E.A. Volumetric rock quality designation. J. Geotech. Engn., Vol 117, No 9, 1991, pp 1331 - 1346.

[20] Sen Z. and Eissa E.A. Rock quality charts for log-normally distributed block sizes. Int. J. Rock Mech. Min. Sci. \& Geomech. Abstr., Vol. 29, No. 1, 1992, pp. 1-12.

[21] Grenon, M. and Hadjigeorgiou, J. Evaluating discontinuity network characterization tools through mining case studies. Soil Rock America, Boston. Vol.1, 2003, pp.137-142.

[22] Palmstrom, A. Measurements of and correlations between block size and Rock Quality Designation (RQD). Journal of Tunneling and Underground space Technology, Vol.20, 2005, pp.362-377. 
[23] Bieniawski, Z.T. Rock mass classification in rock engineering. In Exploration for rock engineering, Proc. of the Symp., (ed. Z.T. Bieniawski). Vol.1, 1976, pp.97-106. Cape Town: Balkema.

[24] Hamasur G. A. Rock Mass Engineering of the Proposed Basara Dam Site, Sulaimani, Kurdistan Region, NE-Iraq. Ph. D. thesis, College of Science, University of Sulaimani / Sulaimani - Iraq, 2009.

[25] Hoek, E., Kaiser, P. K. and Bawden, W. F. Support of underground excavation in hard rock. Rotterdam: Balkema, 1995.

[26] Hoek, E. Putting numbers to geology - an engineer's view point. Quarterly Journal of Engineering Geology, Vol.32, 1999, pp.1-19.

[27] Marinos, P. and Hoek, E. GSI: A geologically friendly tool for rock mass strength estimation. Proc. GeoEng. Conference, Melbourne, 2000, pp.1422-1442.

[28] Sonmez, H., and Ulusay, R. A discussion on the Hoek-Brown failure criterion and suggested modifications to the criterion verified by slope stability case studies. Bulletin of Earth Sciences Application and Research Center of Hacettepe University, Turkey, Yerbilimleri, Vol.26, 2002, pp.77-99.

[29] ISRM. Suggested methods for determining water content, porosity, density, absorption and related properties and swelling and slakedurability index properties. International Society for Rock Mechanics, Commission on Standardization of Laboratory and Field Tests. Int. J. Rock Mech. Min. ScL \& Geomech. Abstr., 16, 1979c, 141-156.

[30] UNIEN 1926. Natural stone methods, Determination of uniaxial compressive strength, European Committee for Standardization, Brussel, 2006.

[31] Barton, N. and Choubey, V. The shear strength of rock joints in theory and practice, Rock Mechanics and Rock Engineering, Vol.10, issue 1-2,1977, pp 1-54

[32] Brook, N. The equivalent core diameter method of size and shape correction in point load testing. Int. J. Rock Mech. Min. Sci. \& Geomech. Abstr. Vol.22, 1985, pp.61-70.

[33] ISRM. Suggested methods for determining point load strength ISRM commission on testing methods, working group on revision of the point load test method. Int.jrn. of rock min Sci. and geomech. Abst. 22, 1985, pp. 51-60.

[34] Rusnak, J. and Mark, C. Using the point load test to determine the uniaxial compressive strength of coal measure rock. 19th Int. Conf. on ground control in mining, Morgantown, WV, 2000, pp.362-371.

[35] Ayday, C. and Grktan, R. M. Correlations between $\mathrm{L}$ and $\mathrm{N}$-type Schmidt hammer rebound values obtained during field-testing. Int. ISRM Syrup. on Rock Characterization, Ed: J. A. Hudson, 1992, pp.47-50.

[36] Deere, D. U., and Miller, R. P. Engineering classification of index properties for intact rock. Technical report No. AFNL-TR-65-116 Air Force weapons laboratory, New Mexico, US, 1966.

[37] Hoek, E., Caranza-Torres, C., Corkum, B. Hoek-Brown failure criterion - 2002 edition. In: Bawden HRW, Curran, J. Telsenicki, M. (eds), Proceeding of the North American Rock Mechanics Society (NARMS - TAC 2002). Mining innovation and Technology, Toronto, 2002, pp.267-273.

[38] Rocscience Inc. RocLab Version 1.033 Rock mass strength analysis using the generalized Hoek-Brown failure criterion. www.rocscience.com, Toronto, Ontario, Canada, 2013.

[39] Hoek, E. and Brown, E. T. Practical estimates of rock mass strength. International Journal Rock Mech. and Mining Sci. and Geomechanics Abstracts, Vol. 34(8), 1997, pp.1165-1186.

[40] Hoek, E. Rock mass properties. Practical Rock Engineering, viewed on 15 May 2008, http://www.rocscience.com/hoek/pdf/11_Roc k_mass_properties.pdf, 2007.

[41] Hoek, E and Diederichs, M. Empirical estimates of rock mass modulus. Int. J Rock Mech. Min. Sci., 43, 2006, pp. 203-215.

[42] Deere, D.u. Geological Considerations Rock Mechanics in Engineering Practice, ed. R.G. Stage and D.C. Zienkiewicz, Wiely. Newyork, 1968, pp.1-20.

[43] Palmstrom, A. and Singh, R. The deformation modulus of rock massesComparison between in situ tests and indirect estimates. Journal of Tunneling and Underground Space Technology, Vol.16, No.3, 2001, pp.115-131. 
[44] Anon. Classification of rocks and soils for engineering geological mapping. Part I-Rock and soil materials', Bull. Int. Ass. Engg Geol., 19, 1979a, pp.364-371.

[45] EN 13755. Natural stone test methods. Determination of water absorption at atmospheric pressure. European Committee for Standardization, Brussel, 2001.

[46] Sousa, L.M.O. Granite fracture index to check suitability of granite outcrops for quarrying. Engineering Geology, Vol. 92 4), 2007, pp.146-159. 